Željko Račić

Visoka poslovna Škola strukovnih studija, Novi Sad raciczeljko@gmail.com

Lidija Barjaktarović

Univerzitet Singidunum lbarjaktarovic@singidunum.ac.rs

Prevod obezbedio

autor
ANALIZA EMPIRIJSKIH DETERMINANTI KREDITNOG RIZIKA U BANKARSKOM SEKTORU REPUBLIKE SRBIJE

Rad predstavlja deo rezultata istraživanja na projektu „Unapređenje konkurentnosti Srbije u procesu pristupanja Evropskoj uniji“, broj 47028, u periodu 2011-2016, koji je finansiralo Ministarstvo za nauku o tehnološki razvoj.

\title{
Rezime
}

Cilj ovog rada je otkrivanje i analiza empirijskih determinanti kreditnog rizika u bankarskom sektoru Republike Srbije. Rad je baziran na analizi rezultata primene linearnog regresionog modela, $\mathrm{u}$ vremenskom periodu od trećeg kvartala 2008. do trećeg kvartala 2014. godine. Tri su osnovna nalaza istraživanja. Prvo, veća kreditna aktivnost banaka doprinosi povećanju udela visoko rizičnih kredita u ukupnim kreditima (zakasneli efekat od 3 godine). Drugo, rast kreditnih plasmana u odnosu na depozite doprinosi većoj izloženosti banaka kreditnom riziku. Treće, faktori koji smanjuju izloženost kreditnom riziku banaka su rast profitabilnosti, rast kamatnog spreda i realni rast bruto domaćeg proizvoda. Imajući u vidu sveukupne tržišne okolnosti i dinamiku privrednog oporavka zemlje, na osnovu rezultata se može izvesti generalni zaključak da će u narednom periodu pitanje visoko rizičnih kredita u Republici Srbiji biti aktuelan izazov i za kreditore i za korisnike kredita.

Ključne reči: bankarski sektor Republike Srbije, empirijske determinante, kreditni rizik, linearni regresioni model. 


\section{ANALYSIS OF EMPIRICAL \\ DETERMINANTS OF CREDIT RISK IN THE BANKING SECTOR OF THE REPUBLIC OF Translation provided by the author SERBIA}

The paper is part of the research results of the project "Improving the Competitiveness of Serbia in the EU Accession Process", number 47028, in the period 2011-2016, financed by the Ministry of Science and Technological Development.

\section{Summary}

The aim of this paper is the detection and analysis of empirical determinants of credit risk in the banking sector of the Republic of Serbia. The paper is based on an analysis of results of the application of the linear regression model, during the period from the third quarter of 2008 to the third quarter of 2014. There are three main findings. Firstly, the higher lending activity of banks contributes to the increasing share of high-risk loans in the total withdrawn loans (delayed effect of 3 years). Secondly, the growth of loans as opposed to deposits contributes to the increased exposure of banks to credit risk. Thirdly, the factors that reduce the exposure of banks to credit risk increase profitability, growth of interest rate spread and real GDP growth. Bearing in mind the overall market conditions and dynamics of the economic recovery of the country, there is a general conclusion based on the results that in the coming period the question of non-performing loans (NPLs) in the Republic of Serbia will present a challenge for both lenders and borrowers.

Keywords: banking sector of the Republic of Serbia, empirical determinants, credit risk, linear regression model. 


\section{Uvod}

U poslednjih deset godina bankarski sektor u Republici Srbiji bio je suočen sa mnogobrojnim izazovima. Nedovoljno brz oporavak privrede (Ranisavljević, Vuković, 2015), delimično uspešna privatizacija državnih preduzeća, svetska ekonomska kriza i globalna politička nestabilnost, samo su neki od faktora koji su pretili da ugroze stabilnost domaćeg bankarskog sektora. Međutim uprkos svemu navedenom, bankarski sektor je ostao stabilan. Konzervativna politika Narodne banke Srbije, fokus banaka na tradicionalnu depozitnokreditnu aktivnost, razvijena konkurencija na bankarskom tržištu i profesionalan odnos bankarskih menadžera prema poslovanju (Matić, 2015), rezultirali su stabilnošću koja se u najkraćem može opisati visokim stepenom likvidnosti i visokom stopom adekvatnosti kapitala.

Stabilnost banaka, u operativnom smislu, najviše zavisi od kvaliteta upravljanja rizicima (Saunders, 2011; Barjaktarović, 2013; Račić i saradnici, 2014). Izloženost kreditnom riziku zavisi od mnogih faktora među kojima se izdvajaju: usklađenost poslovanja sa važećom regulativom, odabir adekvatnih kreditnih strategija i politika, stepen razvijenosti privrede i makroekonomska kretanja na tržištu na kom banke posluju. Empirijski pokazatelj koji se najčešće koristi za utvrđivanje stepena izloženosti banaka kreditnom riziku je udeo visoko rizičnih kredita u ukupnim kreditima (kvalitet aktive). Smatra se da udeo visoko rizičnih kredita svedoči o rastu izloženosti kreditnom riziku i obrnuto.

Grafikon 1. Kretanje udela visoko rizičnih kredita u ukupnim kreditima u Republici Srbiji

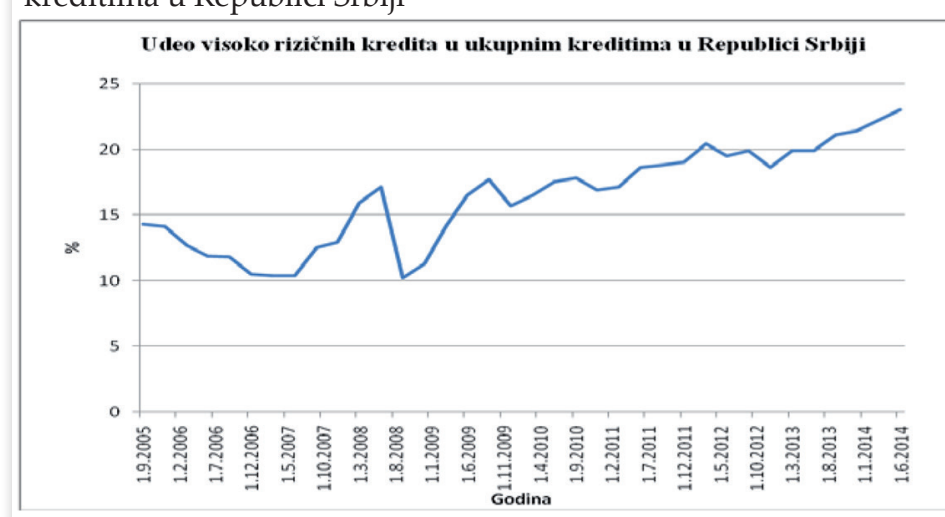

Izvor:Kvartalni izveštaji za bankarski sektor Republike Srbije (www.nbs.rs)
Na grafikonu 1 je prikazano kretanje udela visoko rizičnih kredita u ukupnim kreditima domaćeg bankarskog sektora. Primetno je da nakon udara svetske ekonimske krize udeo visoko rizičnih kredita u ukupnim kreditima beleži trend rasta. Reakcija banaka koja je usledila kao odgovor na krizu, dovela je do pojave smanjenja obima plasmana, rasta likvidnost i smanjenja aktivnih i pasivnih kamatnih stopa. Taj trend bi mogao da rezultira padom udela visoko rizičnih kredita, kao i kreditnom ekspanzijom koja bi upumpavanjem sveže likvidnosti u realni sektor mogla da podstakne budući privredni rast (Izveštaj o rezultatima ankete o kreditnoj aktivnosti, 2015).

Cilj ovog rada je da identifikuje i oceni neke od značajnih empirijskih determinanti izloženosti banaka kreditnom riziku i time pruži doprinos praćenju i analizi izloženosti toj vrsti rizika. Predmet istraživanja su visoko rizični krediti, kao i performanse bankarskog sektora Republike Srbije u segmentu upravljanja kreditnim rizikom, publikovane u kvartalnim izveštajima Narodne banke Srbije o poslovanju banaka u Republici Srbiji, u periodu od 30.09.2008. do 30.06.2014 (Bankarski sektor u Srbiji - kvartalni izveštaji). Istraživanje polazi od generalne hipoteze da makroekonomske i interne karakteristike banaka, determinišu nivo visoko rizičnih kredita u ukupnim kreditima bankarskog sektora u Republici Srbiji.

U skladu sa definisanim ciljem i predmetom istraživanja, rad je organizovan u šest delova. Uvodni deo rada je prvi deo. Pregled literature na temu empirijskih istraživanja o determinantama kreditnog rizika je dat $\mathrm{u}$ drugom delu rada. Metodologija istraživanja je predstavljena $u$ trećem delu rada. Zatim je dat prikaz provere ispunjenosti standardnih pretpostavki linearnog regresionog modela koji je korišćen u istraživanju. Analiza rezultata istraživanja je predstavljena u petom delu, dok su izvedeni zaključci prikazani na kraju, u šestom delu rada.

\section{Pregled literature}

Otkrivanje i analiza empirijskih determinanti 


\section{Introduction}

In the last ten years, the banking sector of the Republic of Serbia has faced numerous challenges. Insufficiently rapid recovery of the economy (Ranisavljević, Vuković, 2015), partially successful privatization of state enterprises, the global financial crisis and political instability are just some of the factors that threatened to jeopardize the stability of the domestic banking sector. However, despite all of the above-mentioned factors, the banking sector has remained stable. The conservative policy of the National Bank of Serbia (NBS), the focus of banks on traditional deposit and lending activities, developed competition in the banking market and professional attitude of banking managers towards their business operations (Matić, 2015) resulted in stability, which further led to a high degree of liquidity and a high capital adequacy ratio.

The stability of banks, in operational terms, is most dependent on the quality of risk management (Saunders, 2011; Barjaktarović, 2013; Račić et al, 2014). The exposure to credit risk depends on many factors including the relation between business operations and the regulations in force, selection of suitable credit strategies and policies, level of development of the country and macroeconomic developments in the market in which banks operate. The empirical indicator which is commonly used for determining the level of banks' exposure to credit risk is the share of NPLs in total loans (asset quality). It is believed that the share of NPLs testifies that there is a growing exposure to credit risk and vice versa.
Chart 1 shows the movement of the share of NPLs in the total loans of the national banking sector. It is notable that under the impact of the global financial crisis the share of NPLs in the total loans showed an upward trend. The reaction of the banks to the crisis led to the reduced volume of investments, liquidity growth and reduction in active and passive interest rates. This trend could result in the fall in the share of NPLs, and credit expansion that could, by pumping fresh liquidity into the real economy, encourage the future economic growth (Report on the results of the survey on lending activities, 2015).

The aim of this paper is to identify and evaluate some of the significant empirical determinants of the exposure of banks to credit risk and thereby contribute to the monitoring and analysis of exposure to this type of risk. The subject of the research are NPLs as well as the performance of the banking sector of the Republic of Serbia in the area of credit risk management, published in the quarterly reports of the National Bank of Serbia on business operations of banks in the Republic of Serbia, in the period from 09/30/2008 to 06/30/2014 (The banking sector of Serbia Quarterly Reports). The study is based on the general hypothesis that the macroeconomic and internal characteristics of banks determine the level of NPLs in the total credit portfolio of the banking sector of the Republic of Serbia.

In accordance with the defined aim and object of the research, the paper is organized in six sections. The introductory part of the paper is its first part. The review of references concerning the empirical research about the determinants of credit risk is provided in the second part. The research methodology is presented in the third part of the paper. This is followed by the overview of the verification of fulfilment of the standard assumptions of the linear regression model used in the research. The analysis of the research results is presented in the fifth part, and the conclusions are presented in the final part of the paper. 
kreditnog rizika zaokuplja pažnju istraživača širom sveta od druge polovine $X X$ veka do danas. Istraživanja uticaja brojnih faktora su rezultirala generalnom ocenom da gubici po osnovu rasta izloženosti kreditnom riziku mogu biti prouzrokovani mnogim mikroekonomskim i makroekonomskim faktorima. U početku je najveći broj istraživanja izvršen na uzorku banaka koje posluju na teritoriji Sjedinjenih Američkih Država, da bi se kasnije istraživanja proširila i na banke iz drugih delova sveta. Faktori koji su najčešće analizirani kao empirijske determinante kreditnog rizika su: bruto domaći proizvod (GDP), inflacija, nezaposlenost, broj filijala i broj zaposlenih u bankama, prinos na aktivu (ROA), prinos na kapital (ROE), neto kamatni prihod, veličina banaka, nivo kapitala, solventnost, kreditna aktivnost, veličina depozitne baze i mnogi drugi (Makri i saradnici, 2014; Ganić, 2014, Das, Ghosh, 2007).

Najveći broj istraživanja banaka u SAD je rezultirao zaključcima da smanjenje efikasnosti $\mathrm{u}$ operativnom poslovanju korisnika kredita dovodi do rasta udela visoko rizičnih kredita i da su manje efikasne i slabije kapitalizovane banke sklone preuzimaju većih rizika (Kwan, Eisenbis, 1997; Berger, DeYoung, 1997). Sa druge strane, istraživanja koja su izvršena u Indiji (Rajaraman i saradnici,1999) su rezultirala zaključcima da mikroekonomske i makroekonomske karakteristike imaju podjednako važan uticaj na kretanje udela visoko rizičnih kredita banaka. Takoje povećanje broja visoko rizičnih kredita pozitivno korelisano sa pogoršanjem makroekonomskih uslova, kao i sa mikroekonomskim faktorima kao što su smanjenje operativne efikasnosti korisnika kredita i ekspanzivno osvajanje novih geografskih tržišta od strane banaka. Istraživanja banaka koje posluju u Španiji (Salas, Saurina, 2002) između ostalog su rezultirala ocenom da rast GDP-a utiče na rast kapaciteta za otplatu kredita privrednih subjekata i stanovništva, što dovodi do pada udela visoko rizičnih kredita u ukupnim kreditnim plasmanima. U istrživanjima koja se odnose na grčke banke je zaključeno da postoji značajna negativna veza između pokazatelja profitabilnosti i kretanja visoko rizičnih kredita (Dimitrios i saradnici, 2012). Na kraju, zaključak koji se može izvesti na osnovu istraživanja makroekonomskih determinanti kreditnog rizika je da visoko rizični krediti pokazuju anticikličnost. To znači da u periodima privrednog rasta njihov udeo $u$ ukupnom kreditnom portfoliju opada i obrnuto (Ganić, 2014). Rast kreditne aktivnosti i rast bankarskih kamatnih stopa su karakteristike uzlazne faze ekonomskog ciklusa, koje nakon njenog prelaska u recesivnu fazu uzrokuju rast udela visoko rizičnih kredita (Jimenez, Saurina, 2005). Rezultati mnogih empirijskih istraživanja to i potvrđuju, jer dobijeni rezultati svedoče da nekoliko godina nakon kreditne ekspanzije dolazi do rasta udela visoko rizičnih kredita u ukupnim kreditnim plasmanima banaka (Salas, Saurina, 2002; Alihodžić, 2015).

\section{Metodologija i podaci}

Dosadašnja istraživanja determinanti kreditnog rizika se pretežno baziraju na primeni dinamičkih panel modela, koji se koriste $\mathrm{u}$ istraživanjima kod kojih se $\mathrm{u}$ obliku nezavisne varijable modela pojavljuju vrednosti zavisne varijable iz ranijih vremenskih perioda (Arellano, Bond, 1991; Bond, 2002; Baltagi, 1995; Baltagi, 2011). Usled nedostatka podataka o udelu visoko rizičnih kredita u ukupnim kreditima na nivou pojedinačnih banaka u Srbiji, u ovom istraživanju je umesto dinamičkih panel modela primenjen višestruki linearni regresioni model (OLS). Ta činjenica ujedno predstavlja nejveće ograničenje istraživanja, jer primena OLS modela može da relativizuje kvalitet dobijenih ocena.

Korišćeni regresioni model se može prikazati sledećim izrazom:

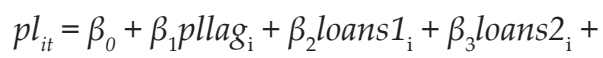

$$
\begin{aligned}
& \beta_{4} \text { loans }_{\mathrm{i}}+\beta_{5} \text { spread }_{\mathrm{i}}+\beta_{6} \text { costoinc }_{\mathrm{i}}+\beta_{7} \text { ROE }_{\mathrm{i}}+ \\
& \beta_{8} \text { lodep }_{\mathrm{i}}+\beta_{9} G D P_{\mathrm{i}}+\varepsilon_{\mathrm{i}}
\end{aligned}
$$

gde je:

$\beta_{0}$ - konstanta modela,

$\beta_{1 . .} \beta_{9}$ - ocene regresionih koeficijenata uz nezavisne varijable modela koji opisuju prirodu $\mathrm{u}$ intenzitet njihovog dejstva na zavisnu varijablu, i,

$\varepsilon_{\mathrm{i}}$ - reziduali modela.

Model je primenjen na osnovu analize kvartalnih podataka konsolidovanih bilansa 


\section{References review}

The identification and analysis of the empirical determinants of credit risk have been attracting the attention of researchers around the world since the second half of the twentieth century. The research on the influence of numerous factors have resulted in a general assessment that losses from the growth of exposure to credit risk can be caused by many microeconomic and macroeconomic factors. In the beginning, the majority of studies were carried out on a sample of banks operating in the territory of the United States, but later the research expanded to include banks in other parts of the world. The factors that are usually analyzed as empirical determinants of credit risk are gross domestic product (GDP), inflation, unemployment, number of branches and number of employees in banks, return on assets (ROA), return on equity (ROE), net interest income, size of banks, the level of capital, solvency, credit activity, the size of the deposit base and the like (Makri et al, 2014; Ganić, 2014, Das, Ghosh, 2007).

Most studies on banks in the United States led to the conclusions that reducing the operating business efficiency of borrowers leads to a rise in the share of NPLs and that less efficient and less capitalized banks tend to take higher risks (Kwan, Eisenbis, 1997; Berger, DeYoung, 1997). On the other hand, the research conducted in India (Rajaraman et al, 1999) resulted in the findings that microeconomic and macroeconomic characteristics have an equally important influence on the movement of the NPLs share. Thus, the increase in the number of NPLs positively correlated with the worsening of the macroeconomic conditions and with micro-economic factors such as the reduction in operational efficiency of the borrower and the expansionist conquest of the new geographical markets by banks. The research on banks operating in Spain (Salas, Saurina, 2002) showed that GDP growth affects the growth of the capacity to repay the loan of business entities and citizens, which leads to a drop in the share of NPLs in the total credit portfolio. The research concerning the Greek banks showed that there is a significant negative relationship between profitability indicators and movements of NPLs (Dimitrios et al, 2012). In the end, the conclusion that can be drawn from the research on macroeconomic determinants of credit risk is that NPLs show counter-cyclicality. This means that in times of economic growth, their share in the total loan portfolio decreases, and vice versa (Ganić, 2014). The growth of lending activities and bank interest rates are the characteristics of the upward stage of the economic cycle, which after its transition to the recession stage cause a growth in the share of NPLs (Jimenez, Saurina, 2005). The results of many empirical studies confirm this, testifying that a few years after the credit expansion there is an increase in the share of NPLs in the total credit portfolio of banks (Salas, Saurina, 2002; Alihodžić, 2015).

\section{Methodology and data}

The previous studies of the determinants of credit risk are primarily based on the use of dynamic panel models, which are used for research purposes when the dependent variable values from the previous periods stand as independent variables (Arellano, Bond, 1991; Bond, 2002; Baltagi, 1995; Baltagi, 2011). Due to the lack of data on the share of NPLs in the total credit portfolio at the level of individual banks in Serbia, in this research we applied the ordinary least squares model (OLS) rather than the dynamic panel models. This fact is also the greatest limitation of the research because the application of OLS models can question the quality of the obtained score.

The applied regression model can be illustrated by the following formula:

$$
\begin{aligned}
& p l_{i t}=\beta_{0}+\beta_{1} \text { pllag }_{\mathrm{i}}+\beta_{2} \text { loans }_{\mathrm{i}}+\beta_{3} \text { loans } 2_{\mathrm{i}}+ \\
& \beta_{4} \text { loans }_{\mathrm{i}}+\beta_{5} \text { spread }_{\mathrm{i}}+\beta_{6} \text { costoinc }_{\mathrm{i}}+\beta_{7} \text { ROE }_{\mathrm{i}}+ \\
& \beta_{8} \text { lodep }_{\mathrm{i}}+\beta_{9} G D P_{\mathrm{i}}+\varepsilon_{\mathrm{i}}
\end{aligned}
$$

with:

$\beta_{0}$ - constant of the model,

$\beta_{1 \ldots} \beta_{9}$ - the scores of the regression coefficients with independent variables that describe the nature of the intensity of their effects on the dependent variable, and

$\varepsilon_{\mathrm{i}}$ - residuals of the model.

The model is applied on the basis of an analysis of quarterly data of the consolidated 
bankarskog sektora u Republici Srbiji, objavljenih $u$ izveštajima Narodne banke Srbije, uz pomoć softverskog paketa STATA 11. Istraživanjem je obuhvaćen vremenski period između 30.09.2008. i 30.06.2014.godine. Opis korišćenih varijabli je prikazan u tabeli 1 . razmatranje se uzima i vrednost $1 /$ VIF, koja bi trebalo da bude veća od 0.1. Rezultati VIF testa su prikazani u tabeli 2 .

Tabela 1. Opis varjabli OLS modela

\begin{tabular}{|c|c|c|c|}
\hline Varijabla & Formula & Prethodna istraživanja & Izvor \\
\hline $\begin{array}{l}\text { pl-zavisna } \\
\text { var. }\end{array}$ & $\begin{array}{l}\text { Udeo zdravih kredita u ukupnim } \\
\text { kreditima (Performing loans) }\end{array}$ & Das, Ghosh, 2007; Makri i saradnici, 2014 & \multirow{9}{*}{$\begin{array}{l}\text { Bankarski sektor u Srbiji } \\
\text { - Kvartalni izveštaji } \\
\text { (www.nbs.rs) }\end{array}$} \\
\hline pllag & $\begin{array}{l}\text { Vrednosti pl varijable, iz istog perioda } \\
\text { prethodne godine - lag } 1 \text { godina }\end{array}$ & Das, Ghosh, 2007; Makri i saradnici, 2014 & \\
\hline Loans 1 & $\begin{array}{l}\text { Udeo kredita u aktivi - vrednosti iz istog } \\
\text { perioda prethodne godine - lag } 1 \text { godina }\end{array}$ & $\begin{array}{l}\text { Das, Ghosh, 2007; Salas, Saurina, 2002; } \\
\text { Ganić, } 2014\end{array}$ & \\
\hline Loans 2 & $\begin{array}{l}\text { Udeo kredita u aktivi iz istog perioda od } \\
\text { pre dve godine - lag } 2 \text { godine }\end{array}$ & $\begin{array}{l}\text { Das, Ghosh, 2007; Salas, Saurina, 2002; } \\
\text { Ganić, } 2014\end{array}$ & \\
\hline Loans 3 & $\begin{array}{l}\text { Udeo kredita } u \text { aktivi iz istog perioda od } \\
\text { pre tri godine - lag } 3 \text { godine }\end{array}$ & $\begin{array}{l}\text { Das, Ghosh, 2007; Salas, Saurina, 2002; } \\
\text { Ganić, } 2014\end{array}$ & \\
\hline Spread1 & $\begin{array}{l}\text { (Kamatni prihodi- Kamatni rashodi)/ } \\
\text { Aktiva- vrednosti iz istog perioda } \\
\text { prethodne godine - lag } 1 \text { godina }\end{array}$ & Das, Ghosh, 2007; Jović, 2015 & \\
\hline Costoinc & $\begin{array}{l}\text { Operativni rashodi/Neto prihod od } \\
\text { kamata, naknada i provizija }\end{array}$ & Das, Ghosh, 2007; Ganić, 2014 & \\
\hline ROE & Prinos na kapital & Ganić, 2014; Makri i saradnici, 2014 & \\
\hline Lodep & Ukupni krediti/Ukupni depoziti & Ganić, 2014; Makri i saradnici, 2014 & \\
\hline GDP & Realni rast bruto domaćeg proizvoda & Das, Ghosh, 2007; Makri i saradnici, 2014 & $\begin{array}{l}\text { Bilten javnih finansija } \\
\text { (www.mfin.gov.rs) }\end{array}$ \\
\hline
\end{tabular}

Izvor: Prikaz autora, NBS, Ministarstvo finansija Republike Srbije

Prilikom tumačenja rezultata je važno uzeti u obzir činjenicu da zavisnu varijablu modela čine varijacije udela zdravih kredita. Dakle, rast vrednosti pl varijable označava smanjenje udela visoko rizičnih kredita u ukupnim kreditnim plasmanima banaka i obrnuto.

\section{Provera ispunjenosti standardnih pretpostavki modela}

Primena OLS modela rezultira pouzdanim ocenama isključivo u slučaju kada su ispunjene standardne pretpostavke modela. U suprotnom su ocene regresionih koeficijenata pristrasne (Mladenović, Petrović, 2007). Iz tog razloga je ispitana ispunjenost osnovnih standardnih pretpostavki višestrukog regresionog modela.

Prva pretpostavka OLS modela se odnosi na odsustvo multikolinearnosti. Multikolinearnost podrazumeva jaku korelaciju između dve ili više nezavisnih varijabli modela. Ispunjenost ove pretpostavke je testirana pomoću VIF testa (Regression with STATA Web book). Varijable čije su VIF vrednosti veće od 10 ne bi trebalo da budu uključene $u$ model. Takođe $u$
Tabela 2. Provera postojanja multikoliearnosti $u$ modelu - VIF test

\begin{tabular}{|l|c|l|}
\hline Varijabla & VIF & 1/VIF \\
\hline loans2 & 8.74 & 0.114 \\
\hline pllag & 8.24 & 0.121 \\
\hline loans3 & 7.17 & 0.139 \\
\hline loans1 & 5.59 & 0.179 \\
\hline lodep & 3.61 & 0.277 \\
\hline costoinc & 3.28 & 0.304 \\
\hline ROE & 2.69 & 0.371 \\
\hline spread1 & 1.92 & 0.521 \\
\hline GDP & 1.70 & 0.589 \\
\hline Prosečan FIV & \multicolumn{2}{|c|}{4.77} \\
\hline
\end{tabular}

Izvor: Proračun autora

Na osnovu rezultata prikazanih $u$ tabeli 2 se može konstatovati da $u$ modelu ne postoji izražena multikolinearnost, odnosno da sve nezavisne varijable mogu da budu uvrštene $u$ model.

Druga pretpostavka koja treba da bude ispunjena se odnosi na normalnost raspodele reziduala. Ispunjenost ove pretpostavka je ispitana primenom Shapiro-Wilk $W$ testa, koji polazi $\mathrm{H}_{0}$ da reziduali imaju normalnu raspodelu. 
balance sheet of the banking sector in the Republic of Serbia published in the reports of the National Bank of Serbia, with the help of the software package STATA 11. The research covered the period between 09/30/2008 and $06 / 30 / 2014$. The description of the variables is shown in Table 1. was tested by the VIF test (Regression with STATA Web book). The variables whose VIF values are greater than 10 should not be included in the model. Also the value of $1 / \mathrm{VIF}$ is taken into consideration, which should be higher than 0.1 . The results of the VIF test are shown in Table 2.

Table 1. Description of variables of the OLS model

\begin{tabular}{|c|c|c|c|}
\hline Variable & Explanation & Earlier research & Source \\
\hline $\begin{array}{l}\text { pl-dependent } \\
\text { variable }\end{array}$ & Performing Loans to total Loans & $\begin{array}{l}\text { Das, Ghosh, 2007; Makri and assistants, } \\
2014\end{array}$ & \multirow{9}{*}{$\begin{array}{l}\text { Banking sector of Serbia } \\
\text { - Quarterly Reports } \\
\text { (www.nbs.rs) }\end{array}$} \\
\hline pllag & $\begin{array}{l}\text { The Values of the pl Variables - } \\
\text { lag } 1 \text { year }\end{array}$ & $\begin{array}{l}\text { Das, Ghosh, 2007; Makri and assistants, } \\
2014\end{array}$ & \\
\hline Loans 1 & Loans to Total Assets - lag 1 year & $\begin{array}{l}\text { Das, Ghosh, 2007; Salas, Saurina, 2002; } \\
\text { Ganić, } 2014\end{array}$ & \\
\hline Loans 2 & Loans to Total Assets - lag 2 years & $\begin{array}{l}\text { Das, Ghosh, 2007; Salas, Saurina, 2002; } \\
\text { Ganić, } 2014\end{array}$ & \\
\hline Loans 3 & Loans to Total Assets - lag 3 years & $\begin{array}{l}\text { Das, Ghosh, 2007; Salas, Saurina, 2002; } \\
\text { Ganić, } 2014\end{array}$ & \\
\hline Spread1 & $\begin{array}{l}\text { (Interest Income Less Interest } \\
\text { Expense) / total asset-lag } 1 \text { year }\end{array}$ & Das, Ghosh, 2007; Jović, 2015 & \\
\hline Costoinc & $\begin{array}{l}\text { Operating Expenses / Net Interest } \\
\text { Income }\end{array}$ & Das, Ghosh, 2007; Ganić, 2014 & \\
\hline ROE & Return on Equity & Ganić, 2014; Makri and assistants, 2014 & \\
\hline Lodep & Loans to Deposit Ratio & Ganić, 2014; Makri and assistants, 2014 & \\
\hline GDP & Growth Rate of Real GDP & $\begin{array}{l}\text { Das, Ghosh, 2007; Makri and assistants, } \\
2014\end{array}$ & $\begin{array}{l}\text { Public Finance Bulletin } \\
\text { (www.mfin.gov.rs) }\end{array}$ \\
\hline
\end{tabular}

Source: The overview prepared by the authors, NBS, Ministry of Finance of the Republic of Serbia

When interpreting the results, it is important to take into account the fact that the dependent variable model includes the variations of the share of the proper loans. Thus, the growth in the value of $\mathrm{pl}$ variable indicates a decrease in the share of NPLs in the total credit portfolio of banks, and vice versa.

\section{Checking the fulfilment of the standard assumptions of the model}

The application of OLS model results in reliable assessments only in case of the fulfilment of the standard assumptions of the model. Otherwise, the assessments of the regression coefficients are biased (Mladenović, Petrović, 2007). For this reason we examined the fulfilment of the basic standard assumptions of the multiple regression model.

The first assumption of the OLS model refers to the absence of multicollinearity. Multicollinearity implies a strong correlation between two or more independent variables of the model. The fulfilment of this assumption
Table 2. Checking the existence of multicollinearity in the model - VIF test

\begin{tabular}{|l|c|c|}
\hline VARIABLE & VIF & 1/VIF \\
\hline loans2 & 8.74 & 0.114 \\
\hline pllag & 8.24 & 0.121 \\
\hline loans3 & 7.17 & 0.139 \\
\hline loans1 & 5.59 & 0.179 \\
\hline lodep & 3.61 & 0.277 \\
\hline costoinc & 3.28 & 0.304 \\
\hline ROE & 2.69 & 0.371 \\
\hline spread1 & 1.92 & 0.521 \\
\hline GDP & 1.70 & 0.589 \\
\hline Average $F I V$ & \multicolumn{2}{|c|}{4.77} \\
\hline
\end{tabular}

Source: The calculation made by the authors

According to the results shownin Table2itcan be concluded that there is no multicollinearity in the model, i.e. all independent variables can be included in the model.

Another assumption that needs to be fulfilled refers to the normality of the distribution of residuals. The fulfilment of this assumption is tested using the Shapiro-Wilk W test, which starts from $\mathrm{H}_{0}$ that the residuals have a normal distribution. 
Tabela 3. Provera normalnosti raspodele reziduala - Shapiro-Wilk W test

\begin{tabular}{|c|c|c|c|c|c|}
\hline Varijabla & $\begin{array}{c}\text { Broj } \\
\text { opservacija }\end{array}$ & W & V & z & Prob $>$ z \\
\hline r & 24 & 0.99021 & 0.264 & -2.715 & 0.99669 \\
\hline
\end{tabular}

Izvor: Proračun autora

Na osnovu P-vrednosti ( $\mathrm{P}=0.99669)$ se može konstatovati da se $\mathrm{H}_{0}$ potvrđuje, što znači da reziduali imaju normalnu raspodelu. Vizuelni prikaz raspodele reziduala modela je dat na slici 1.

Slika 1. Prikaz raspodele reziduala modela Kernel density estimate

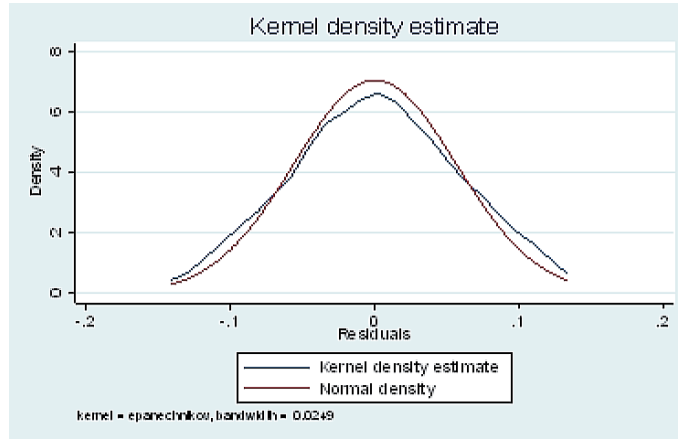

Izvor: Proračun autora (STATA 11)

Sledeća pretpostavka se odnosi na proveru homoskedastičnosti slučajnih grešaka. Slučajne greške bi trebalo da pokazuju isti stepen rasejanja oko svoje srednje vrednosti. Ukoliko se varijanse slučajnih grešaka međusobno značajno razlikuju, za slučajne greške kažemo da su heteroskedastične. Homoskedastičnost reziduala je proverena primenom Cameron $\mathcal{E}$ Trivedi's decomposition of IM testa i BreuschPagan/Cook-Weisberg testa. Rezultati primene testova su prikazani u tabeli 4 .

Tabela 4. Testovi heteroskedastičnosti reziduala

\begin{tabular}{|c|c|c|c|}
\hline \multicolumn{4}{|c|}{ Cameron $\mathcal{E}$ Trivedi's decomposition of IM test } \\
\hline Source & Chi2 & df & $\mathrm{p}$ \\
\hline Heteroskedascity & 24.00 & 23 & 0.4038 \\
\hline Skewness & 13.01 & 9 & 0.1620 \\
\hline Kurtosis & 0.59 & 1 & 0.4416 \\
\hline Total & 37.61 & 33 & 0.2664 \\
\hline \multicolumn{4}{|c|}{$\begin{array}{l}\text { Breusch-Pagan/Cook-Weisberg test postojanja } \\
\text { heteroskedastičnosti reziduala }\end{array}$} \\
\hline \multicolumn{4}{|c|}{$\mathrm{H}_{0}:$ Konstantna varijansa } \\
\hline \multicolumn{2}{|c|}{ Chi2(1) } & \multicolumn{2}{|c|}{0.64} \\
\hline \multicolumn{2}{|l|}{ Prob>chi2 } & \multicolumn{2}{|c|}{0.4239} \\
\hline
\end{tabular}

Izvor: Proračun autora
Na osnovu P-vrednosti Breusch-Pagan/CookWeisberg testa koji polazi od $\mathrm{H}_{0}$ da je varijansa reziduala konstantna, možemo konstatovati da u modelu ne postoji izražena heteroskedastičnost (Prob>chi2=0.4239). Vizuelni prikaz rasrejanja slučajne greške oko svoje srednje vrednosti prikazan je na slici 2 .

Slika 2. Prikaz homoskedastičnosti reziduala

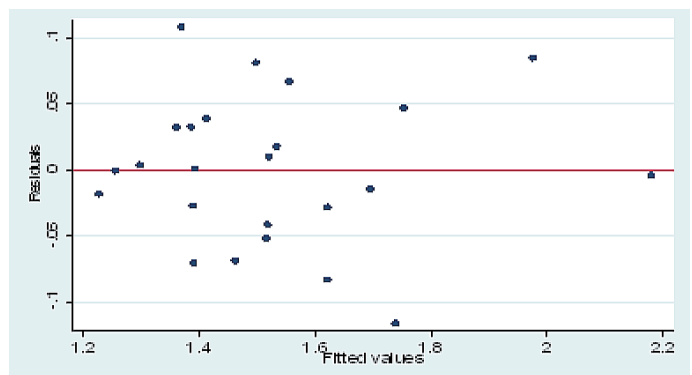

Izvor: Proračun autora (STATA 11)

Poslednji korak statističke obrade podataka se odnosi na otklanjanje autokorelacije reziduala, koja je u slučaju vremenskih serija veoma često prisutna. Za otkrivanje autokorelacije je korišćen Durbin-Watson test, dok je u svrhu njenog otkanjanja primenjen Cochrane-Orcutt model (Newbold, 2010; Mladenović, Petrović, 2007). Dobijeni rezultati su prikazani u tabeli 5 .

Tabela 5. Konačni rezultati primene linearnog regresionog modela

\begin{tabular}{|c|c|c|}
\hline \multicolumn{3}{|c|}{ Cochrane-Orcutt AR(1) regression } \\
\hline \multicolumn{3}{|c|}{ Broj opservacija: 23} \\
\hline \multicolumn{3}{|c|}{ Prob $>F=0.0000$} \\
\hline \multicolumn{3}{|c|}{ R-squared= 0.9622 (koeficijent determinacije) } \\
\hline \multicolumn{3}{|c|}{$\begin{array}{l}\text { Adj R-squared=0.9360 (modifikovani koeficijent } \\
\text { determinacije) }\end{array}$} \\
\hline $\begin{array}{l}\text { Nezavisne } \\
\text { varijable }\end{array}$ & $\begin{array}{l}\text { Ocene regresionih } \\
\text { koeficijenata }\end{array}$ & $\begin{array}{l}\text { Standardne } \\
\text { greške }\end{array}$ \\
\hline pllag & $0.3894^{* * *}$ & 0.06941 \\
\hline loans1 & $1.4243^{* *}$ & 0.5159 \\
\hline loans2 & 0.6792 & 0.4712 \\
\hline loans3 & $-1.4906^{* *}$ & 0.5561 \\
\hline spread1 & $4.3013^{* *}$ & 1.5248 \\
\hline costoinc & -0.2458 & 1.0896 \\
\hline roe & $4.0022^{* * *}$ & 0.8847 \\
\hline lodep & $-0.9060^{* *}$ & 0.3819 \\
\hline gdp & $2.5202^{* *}$ & 0.8595 \\
\hline _cons & 1.1957 & 1.0573 \\
\hline \multicolumn{2}{|c|}{ Durbin-Watson statistic (original) } & 2.280142 \\
\hline \multicolumn{3}{|c|}{ Durbin-Watson statistic (transformed) } \\
\hline
\end{tabular}

Napomena: (signifikantnost 90\%), ** (signifikantnost 95\%), **** (signifikantnost 99\% ) 
Table 3. Checking the regularity of the distribution of residuals - Shapiro-Wilk $W$ test

\begin{tabular}{|c|c|c|c|c|c|}
\hline Variable & $\begin{array}{c}\text { Number of } \\
\text { obs. }\end{array}$ & $\mathrm{W}$ & $\mathrm{V}$ & $\mathrm{z}$ & Prob $>\mathrm{z}$ \\
\hline $\mathrm{r}$ & 24 & 0.99021 & 0.264 & -2.715 & 0.99669 \\
\hline
\end{tabular}

Source: The calculation made by the authors

According to $\mathrm{P}$-values $(\mathrm{P}=0.99669)$ it can be seen that $\mathrm{H}_{0}$ is confirmed, which means that the residuals have a normal distribution. The visual representation of the distribution of the residuals of the model is given in Figure 1.

Figure 1. The representation of the distribution of the residuals of the model - Kernel density estimate

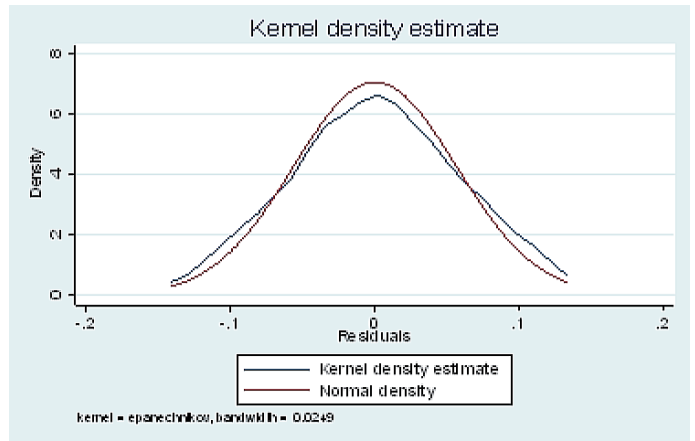

Source: The calculation made by the authors (STATA 11)

The next assumption relates to the checking of homoscedasticity of random errors. Random errors should show the same degree of scattering around their mean value. If the variance of random errors differs significantly, the random errors are called heteroscedastic. Heteroscedasticity of residuals was checked by applying Cameron $\mathcal{E}$ Trivedi's decomposition of IM test and Breusch-Pagan/Cook-Weisberg test. The results of these tests are shown in Table 4.

Table 4. Tests of heteroscedasticity of residuals

\begin{tabular}{|l|c|c|c|}
\hline Cameron E Trivedi's decomposition of IM test \\
\hline Source & Chi2 & $\mathrm{df}$ & $\mathrm{p}$ \\
\hline Heteroscedasticity & 24.00 & 23 & 0.4038 \\
\hline Skewness & 13.01 & 9 & 0.1620 \\
\hline Kurtosis & 0.59 & 1 & 0.4416 \\
\hline Total & 37.61 & 33 & 0.2664 \\
\hline Breusch-Pagan/Cook-Weisberg test \\
\hline H$_{0}$ : Constant variance & \multicolumn{2}{|c|}{0.64} \\
\hline Chi2(1) & \multicolumn{2}{|c|}{0.4239} \\
\hline Prob>chi2
\end{tabular}

Source: The calculation made by the authors
Based on the P-value of Breusch-Pagan/ Cook-Weisberg test that starts from $\mathrm{H}_{0}$ and shows that the variance of the residuals is constant, we can conclude that there is no expressed heteroscedasticity in the model (Prob $>$ chi2 $=0.4239)$. The visual representation of scattering of random errors around its mean value is shown in Figure 2.

\section{Figure 2. The representation of homoscedasticity} of residuals

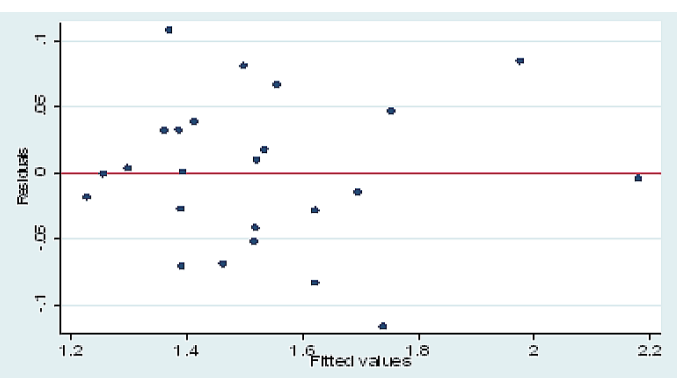

Source: The calculation made by the authors (STATA 11)

The last step in the statistical processing of data relates to the elimination of autocorrelation of residuals, which is often present in the case of time series. Durbin-Watson test is used to detect autocorrelation, while for the purpose of its elimination we applied Cochrane-Orcutt model (Newbold, 2010; Mladenović, Petrović, 2007). The obtained results are shown in Table 5.

Table 5. The final results of the application of the linear regression model

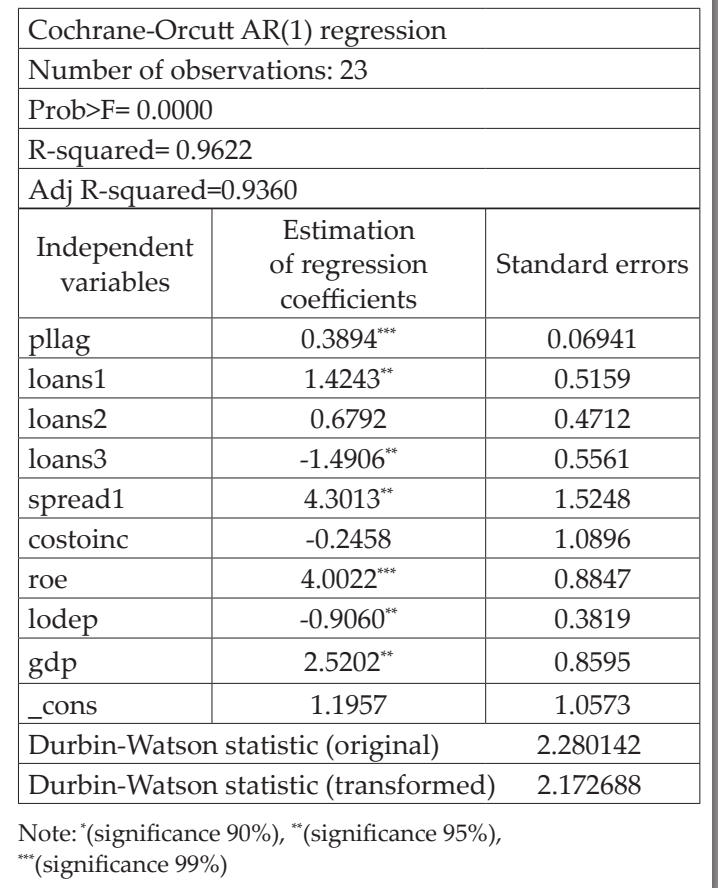


$\mathrm{Na}$ osnovu dobijenih ocena regresionih koeficijenata izvršena je analiza uticaja posmatranih varijabli (determinanti) na izloženost bankarskog sektora Republike Srbije kreditnom riziku.

\section{Analiza rezultata istraživanja}

Dobijeni rezultati idu u prilog oceni da je korišćeni model adekvatan za analizu odnosa između posmatranih promenljivih (Prob $>\mathrm{F}=$ 0.0000). Na osnovu vrednosti koeficijenta determinacije se može izvesti zaključak da je 93.6\% varijacija udela visoko rizičnih kredita u ukupnim kreditima objašnjeno varijacijama razmatranih regresora (Adj R-squared=0.9360). Varijable koje na statistički značajnom nivou determinišu udeo visoko rizičnih kredita su: pllag, loans1, loans3, spread1, roe, lodep i gdp.

Varijacije kreditne aktivnosti su prva karakteristika koja determiniše izloženost banaka kreditnom riziku. U radu je razmatran uticaj kreditne aktivnosti banaka iz perioda od pre jedne, dve i tri godine godine $u$ odnosu na trenutak posmatranja nivoa visoko rizičnih kredita. Drugim rečima, razmatran je zakasneli efekat varijacija kreditne aktivnosti na posmatranu izloženost. Dobijene ocene idu u prilog zaključku da godinu dana nakon rasta kreditne aktivnosti dolazi do smanjenja udela visoko rizičnih kredita (Ganić 2014), dok nakon tri godine dolazi do povećanja njihovog udela u ukupnim kreditima (Salas, Saurina, 2002). Osvrnućemo se na neke od značajnih faktora koji tome doprinose. Bankarsko tržište u Republici Srbiji pokazuje znakove zasićenja. Uprkos niskom ukupnom nivou koncetracije (Herfindal-Hiršmanov indeks), tržišno učešće prvih pet banaka u bilansnoj sumi sektora beleži kontinuiran rast, što značajno determiniše nivo visoko rizičnih kredita u ukupnom kreditnom portfoliju (Dimić, 2015). Takođe, važno je ukazati i na činjenicu da banke predominantno odobravaju kredite sa valutnom klauzulom, usled čega sejavlja problem izloženosti deviznom riziku koji je tokom analiziranog vremenskog perioda značajno doprineo rastu udela visoko rizičnih kredita. Primarni izvori otplate korisnika kredita su u dinarima, dok su obaveze vezane za kurs evra (ili švajcarskog franka), koji fluktuira i ugrožava kreditnu sposobnost korisnika kredita.
Ublažavanju kreditnih standarda može da doprinese i smanjenje razlike između kamatonosnih prihoda i kamatonosnih rashoda banaka. Domaće banke profitabilnost oslanjaju na kamatonosne prihode, zbog pretežne orijentacije na kreditno-depozitnu aktivnost. To znači da smanjenje razlike između kamatonosnih prihoda i kamatonosnih rashoda preti da ugrozi njihovu profitabilnost. Smanjenje profitabilnosti može da uslovi korekciju kreditne politike banaka u pravcu ublažavanja kreditnih standarda, sa ciljem da po osnovu većih premija za kreditni rizik (koje proističu iz rizičnijih plasmana a uključene su u kamatni spred) održe profitabilnost na željenom nivou. Imajući u vidu sveukupne tržišne okolnosti, može se zaključiti da ublažavanje kreditnih standarda povećava izloženost banaka kreditnom riziku. To potvrđuju i rezultati istraživanja, koji idu u prilog oceni da smanjenje kamatnog spreda rezultira povećanjem udela visoko rizičnih kredita u ukupnim kreditnim plasmanima banaka.

Sledeća karakteristika banaka koja determiniše izloženost kreditnom rizikuje njihova profitabilnost (ROE). Prethodna istraživanja ocenjuju da profitabilne banke imaju manje motiva za izlaganje rizičnim kreditnim plasmanima (Makri i saradnici, 2014). Rezultati našeg istraživanja potvrđuju ocenu da smanjenje profitabilnosti utiče na rast udela visoko rizičnih kredita u ukupnim kreditima, što smanjuje mogućnost da se kreditni gubici pokriju iz operativnog prihoda (pokrivaju se iz kapitala). Tome u prilog ide negativna korelacija između stope adekvatnosti kapitala i udela visoko rizičnih kredita, koja je unutar obuhvaćenog vremenskog intervala iznosila @=0.53 (Pirsonov koeficijent), uz napomenu da je početkom 2013 godine vrednost tog koeficijenta iznosila čak $\mathrm{Q}=-0.82$.

Varijacije količnika plasiranih kredita i depozita banaka takođe predstavljaju značajnu determinantu posmatrane izloženosti. Prethodna istraživanja ocenjuju da je kretanje ovog koeficijenta pozitivno korelisano sa kretanjem udela visoko rizičnih kredita (Ganić, 2014; Makri i saradnici, 2014). To je u skladu i sa rezultatima našeg istraživanja, koji ocenjuju da rast kreditne aktivnosti $\mathrm{u}$ odnosu na depozitnu bazu utiče na povećanu izloženost 
On the basis of the obtained scores of regression coefficients, we analyzed the impact of the observed variables (determinants) on the exposure of the banking sector of the Republic of Serbia to credit risk.

\section{Analysis of the research results}

The results support the assessment that the applied model is suitable for the analysis of the relationship between the observed variables (Prob $>F=0.0000)$. Based on the value of the coefficient of determination it can be concluded that $93.6 \%$ of the variation of the share of NPLs in the total loans is explained by the variations of the observed regresses (Adj R-squared=0.9360). The variables that in the statistically significant level determine the proportion of NPLs are pllag, loans1, loans3, spread1, roe, lodep and gdp.

The variations of lending activities are the first characteristic that determines the exposure of banks to credit risk. The paper examines the impact of the banks' credit activity in the period of one, two and three years ago in relation to the moment of observing the level of NPLs. In other words, we considered the delayed effect of variations in credit activity on the observed exposure. The estimates support the conclusion that one year after the credit growth there is a reduction in the share of NPLs (Ganić 2014), while after three years there is an increase in their share in total loans (Salas, Saurina, 2002). We will now examine some of the significant factors contributing to this. The banking market in Serbia is showing signs of saturation. Despite the low overall level of concentration (Herfindahl-Hirschman Index), the market share of the top five banks in the balance sheet recorded a continuous growth, which significantly determines the level of NPLs in the total loan portfolio (Dimić, 2015). Also, it is important to draw attention to the fact that banks predominantly grant loans with a foreign currency clause, causing the problem of exposure to currency risk, which during the analyzed time period contributed significantly to the rise in the share of NPLs. The borrowers' primary sources of repayment are in dinars, while their obligations are indexed in FX (i.e. EUR or CHR exchange rate), which fluctuates and threatens the creditworthiness of the borrowers.
A contribution to the credit standards improvement can also be the reduced difference between the banks' interest-based revenues and expenditures. The profitability of domestic banks relies on interest income, due to the predominant orientation to the credit-deposit activity. This means that a reduction in the difference between interest-based revenues and expenditures threatens to jeopardize their profitability. A decrease in profitability may require an adjustment of the credit policy of banks to relax the lending standards, with the aim of maintaining profitability at the desired level with higher credit risk premiums (arising from risky investments and being included in the interest rate spread). Bearing in mind the overall market conditions, it can be concluded that the easing of credit standards increases the exposure of banks to credit risk. This is confirmed by the research results that support the assessment that the reduction in interest rate spread results in an increased share of NPLs in the total credit portfolio of banks.

Another feature of banks that determines their exposure to credit risk is their profitability (ROE). The previous studies estimate that profitable banks are less motivated to expose themselves to risky credit placements (Makri et al, 2014). The results of our research confirm the assessment that the reduction in profitability affects the growth of the share of NPLs in the total credit portfolio, which reduces the possibility to cover credit losses from operating income (covered from equity). This is supported by the negative correlation between the rate of capital adequacy ratio and the share of NPLs, which was, within the covered time period, Q $=-0.53$ (Pearson coefficient), noting that at the beginning of 2013 the value of this coefficient was as high as $\mathrm{Q}=-0.82$.

Variations in the loans-to-deposits ratio also represent a significant determinant of the observed exposure. The previous studies show that the trends of this ratio are positively correlated with the trends of the share of NPLs (Ganić, 2014; Makri et al, 2014). This is in accordance with the results of our study, which assessed that the growth of credit activity in relation to the deposit base affects the increased exposure of banks to credit risk. One of the important reasons for this is the 
banaka kreditnom riziku. Jedan od značajnih razloga za to jeste činjenica da su domaće banke prelikvidne i da nisu zainteresovane da prikupljaju depozite jer nemaju po njihovom mišljenju zdrave projekte $\mathrm{u}$ koje bi plasirali sredstva (kredite), dok vlasnici viška novčanih sredstava nisu motivisani potencijalnim prinosom (visinom kamatne stope) da investiraju u depozite poslovnih banaka.

Poslednja značajna varijabla kreditnog rizika koja je obuhvaćena ovim istraživanjem je kretanje realnog rasta GDP-a. Ocenjena negativna veza između kretanja realnog rasta GDP-a i udela visoko rizičnih kredita je takođe u skladu sa rezultatima prethodnih istraživanja (Das, Ghosh, 2007; Jović, 2015; Makri i saradnici, 2014). Rast GDP-a utiče na povećanje sredstava za otplatu kredita kod korisnika kredita iz sektora privrede i stanovništva, što ima za posledicu smanjenje udela vioko rizičnih kredita u ukupnom kreditnom portfoliju. Kada je u pitanju privredni rast u Republici Srbiji, nakon udara svetske ekonomske krize domaća privreda je pretežno bila suočena sa periodima stagnacije i recesije, što je jedan od osnovnih razloga za jaču izloženost banaka kreditnom riziku u tom periodu.

\section{Zaključak}

Istraživanje empirijskih determinanti izloženosti bankarskog sektora Republike Srbiji kreditnom riziku je rezultairalo zaključcima koji potvrđuju generalnu hipotezu. To znači da makroekonomske i interne karakteristike banaka, na statistički značajnom nivou determinišu nivo visoko rizičnih kredita $\mathrm{u}$ ukupnim kreditima bankarskog sektora $\mathrm{u}$ Republici Srbiji. Rezultati idu u prilog oceni da rast kreditne aktivnosti bankarskog sektora nakon vremenskog perioda od tri godine ima za posledicu povećanje udela visoko rizičnih kredita u ukupnim kreditnim plasmanima. Isti efekat na udeo visoko rizičnih kredita ostvaruje smanjenje razlike između kamatonosnih prihoda i kamatonosnih rashoda, kao i rast kreditne aktivnosti u odnosu na depozite. Takođe, može se izvesti zaključak da profitabilnije banke imaju manji udeo visoko rizičnih kredita, što znači da su manje izložene kreditnom riziku.

Imajući u vidu sveukupne tržišne okolnosti i dinamiku privrednog oporavka, može se izvesti generalni zaključak da će u narednom periodu pitanje visoko rizičnih kredita u Republici Srbiji biti aktuelan izazov i za kreditore i za korisnike kredita. Fokus menadžera bi trebao da bude usmeren na rešavanju sledećih pitanja. Prvo, kako na vreme pripremiti odgovarajući "Early Warning System" i prepoznati potencijalne visoko rizične kredite i preventivno ih rešiti. Drugo, koje mehanizme iskoristiti da se odovarajućim restrukturiranjem omogući korisniku kredita da nastavi uspešno da posluje u slučaju da prevencija ne pomaže. I na kraju, kako prepoznati u kom trenutku mogu da se uključe turn-around manager-i ili da se proda visoko rizičan plasman specijalizovanom investicionom fondu koji će korisniku kredita pomoći da uspešno prevaziđe krizu i nastavi profitabilno da posluje. 
fact that domestic banks are too liquid and not interested in collecting deposits because they do not have, in their opinion, reliable projects in which to invest their assets (loans), while the owners of surplus funds are not motivated by the potential yield (the interest rate) to invest in commercial banks' deposits.

The last significant variable of credit risk covered by this research is the trend of real GDP growth. The estimated negative relationship between the movement of the real GDP growth and the share of NPLs is also in line with the previous findings (Das, Ghosh, 2007; Jović, 2015; Makri et al, 2014). The GDP growth causes an increase in the funds for repayment of loans by retail and corporate borrowers, which results in a reduction of the share of NPLs in the total credit portfolio. When it comes to the economic growth in the Republic of Serbia, after the impact of the global economic crisis, the national economy was mainly faced with the periods of stagnation and recession, which is one of the main reasons for the higher banks' exposure to credit risk during this period.

\section{Conclusion}

The study of empirical determinants of exposure of the banking sector of the Republic of Serbia to credit risk led to the conclusions that confirm the general hypothesis. This means that macroeconomic and internal characteristics of banks in statistical terms significantly determine the level of NPLs in the total credit portfolio of the banking sector of the Republic of Serbia. The results support the assessment that the growth of credit activity of the banking sector after a period of three years resulted in the increase in the share of NPLs in the total credit portfolio. The same effect on the share of NPLs is realized through the reduction in the difference between interest-based revenues and expenditures, and an increase in credit activity in relation to deposits. Also, it can be concluded that profitable banks have a smaller share of NPLs, which means that they are less exposed to the credit risk.

Bearing in mind the overall market conditions and the dynamics of economic recovery, it can be concluded that in the future the issue of NPLs in the Republic of Serbia will present a challenge both for lenders and borrowers. The focus of managers should be on addressing the following questions. Firstly, how to prepare the appropriate "Early Warning System", identify the potential high-risk loans and address them preventively. Secondly, what mechanisms should be used to provide the borrowers with the suitable restructuring and thus enable them to continue to operate successfully if prevention does not help? Finally, how to identify at what point the turn-around managers should be involved, and how to sell NPLs to the specialized investment funds that will help the borrower to successfully overcome the crisis and continue to operate profitably. 


\section{Literatura / References}

1. Alihodžić A. 2015. Međusobna uslovljenost performansi bankarskog i realnog sektora Republike Srbije. Bankarstvo 44, (2): 46-71.

2. Arellano M., Bond S. 1991. Some tests of specification for panel data: Monte Carlo evidence and an application to employment equations. The Review of Economic Studies 58, (2): 277-297.

3. Baltagi B. H. 1995. Econometric analysis of panel data (3rd ed.). West Sussex, England: John Wiley \& Sons, Ltd

4. Baltagi B. H. 2011. Econometrics. Berlin, Heidelberg: Springer Berlin Heidelberg

5. Bankarski sektor u Srbiji - kvartalni izveštaji. Beograd: Narodna banka Srbije, Sektor za kontrolu poslovanja banaka (http://www. nbs.rs/internet/cirilica/55/55_4/index.html, 10.12.2015)

6. Barjaktarović L. 2013. Upravljanje rizikom. Beograd: Univerzitet Singidunum

7. Berger A. N., DeYoung R. 1997. Problem loans and cost efficiency in commercial banks. Journal of Banking and Finance 21: 849-870

8. Bilten javnih finansija, broj 124. decembar 2014. Republika Srbija: Ministarstvo Finansija, (http://www.mfin.gov.rs/ UserFiles/File/bilten\%20javne\%20finansije/ bilten-124-web.pdf, 01.02.2016)

9. Bond S. R. 2002. Dynamic panel data models: A guide to micro data methods and practice. Portuguese Economic Journal 1, (2): 141-162
10. Dimić, M., Analiza nivoa koncentracije u bankarskom sektoru u zemljama centralne i istočne Evrope. Univerzitet Singidunum, 2015

11. Dimitrios P. L., Angelos T. V., Vasilios L. M. 2012. Macroeconomic and bank-specific determinants of non-performing loans in Greece: A comparative study of mortgage, business and consumer loan portfolios. Journal of Banking \& Finance 36, (4): 10121027

12. Das A., Ghosh S. 2007. Determinants of Credit Risk in Indian State-owned Banks: An Empirical Investigation. MPRA Paper No. 17301, posted 16. September 2009, (http://mpra.ub.uni-muenchen.de/17301/ ,10.02.2016)

13. Ganić M. 2014. Bank Specific Determinants of Credit Risk - An Empirical Study on the Banking Sector of Bosnia and Herzegovina. International Journal of Economic Practices and Theories 4, (4): 428- 436

14. Izveštaj o rezultatima ankete o kreditnoj aktivnosti - prvo tromesečje 2015. maj 2015. Beograd: Narodna banka Srbije (http:// www.nbs.rs/export/sites/default/internet/ latinica/90/anketa_kab/kab_izv_I_2015.pdf, 15.12.2015)

15. Jimenez G., Saurina J. 2005. Credit cycles, credit risk, and prudential regulation. Banco de España. (http://www.bis.org/bcbs/events/ rtf05JimenezSaurina.pdf, 30.01.2016) 
16. Jović D. 2015. Modeliranje loših kredita u bankarskom sektoru Bosne i Hercegovine. Bankarstvo 44, (3): 78-101

17. Kwan S., Eisenbis R. 1997. Bank Risk, capitalisation and operating efficiency. Journal of Financial Services Research 12: 117-131.

18. Makri V., Tsagkanos A., Bellas A. 2014. Determinants of non-performing loans: The case of Eurozone. Paneconomicus 61, (2): 193-206

19. Matić V. 2015. Ublažavanje izloženosti pristupi i priznati istrumenti. Bankarstvo 44, (2): 150-153

20. Mladenović M., Petrović P. 2007. Uvod u ekonometriju. Beograd: Centar za izdavačku delatnost Ekonomskog fakulteta u Beogradu.

21. Newbold P., Carlson W L., Thorne B. 2010. Statistika za poslovanje i ekonomiju. Zagreb: MATE

22. Račić Ž., Stanišić N., Račić M. 2014. A Comparative Analysis of the Determinants of Interest Rate Risk Using the Example of Banks from Developed and Developing Financial Markets. Engineering Economics 25, (4): 395-400
23. Rajaraman I., Bhaumik S., Bhatia N. 1999. NPA variations across Indian commercial banks: some findings. Economic and Political Weekly 34, (3/4): 16-23

24. Ranisavljević D., Vuković D. 2015. Rizici kreditiranja malog biznisa u Republici Srbiji. Bankarstvo 44, (1): 12-25

25. Regression with STATA Web book: Chapter 2, Regression Diagnostics. Institute for digital research and education ( http:// www.ats.ucla.edu/Stat/stata/webbooks/reg/ chapter2/statareg2.htm, 07.02.2016)

26. Salas V., Saurina J. 2002. Credit Risk in Two Institutional Regimes: Spanish Commercial and Saving Banks. Journal of Financial Services Research 22, (3): 203-224.

27. Saunders A., Cornet M. M. 2011. Financial institutions management - A Risk Management Approach. International edition: McGrawHill 